\title{
$M_{\text {IDdLe }} \boldsymbol{E}_{\text {ast }} \boldsymbol{S}_{\text {tUdies }}$ Association BULLETIN
}

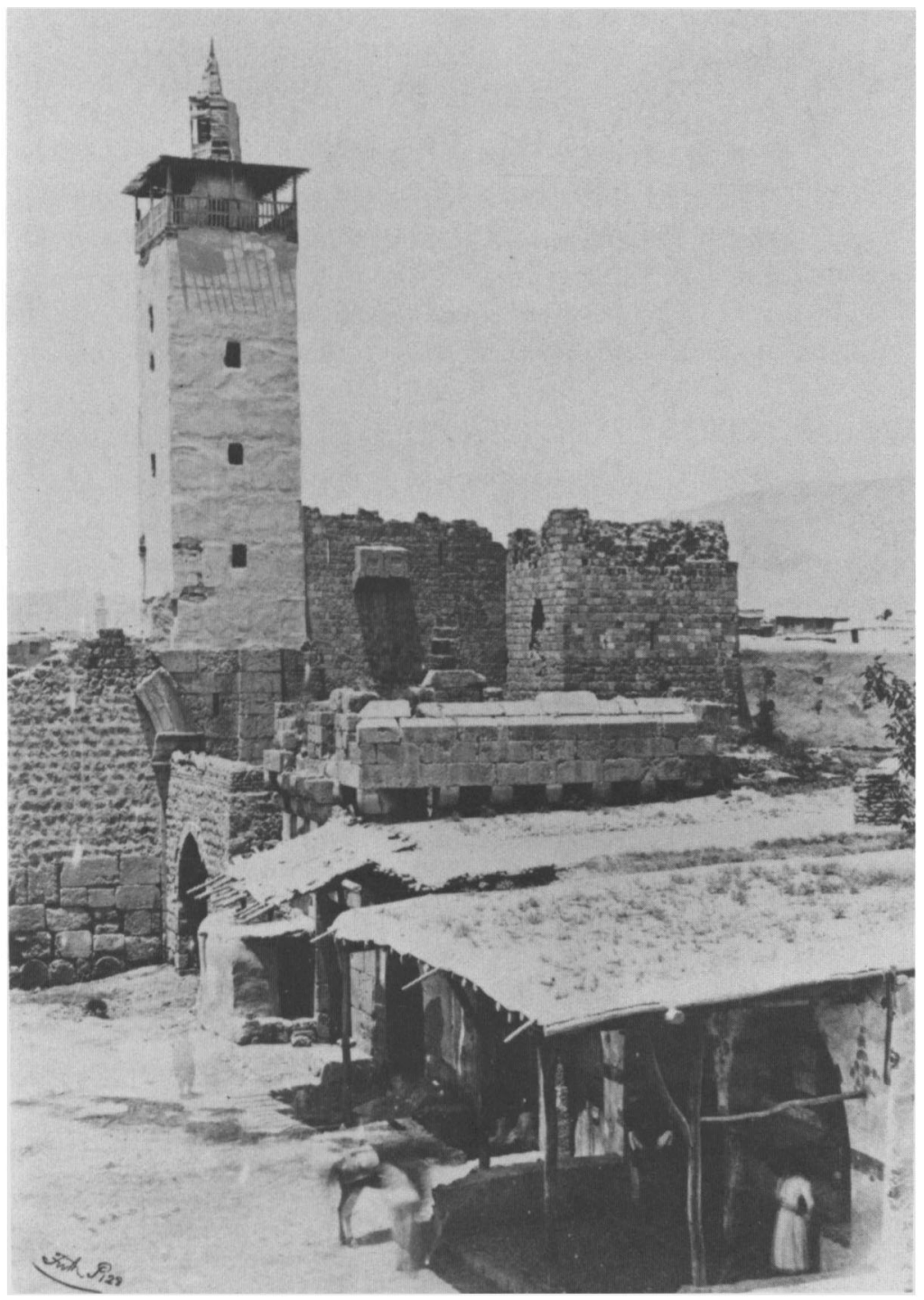


Editor: JERE L. BACHARACH

Assistant Editor: THEODORA S. MACKAY

Book Review Committee

History and Political Science:

Arab East and Turkey: BENJAMIN BRAUDE

Arab West: LISA ANDERSON

Iran and Afghanistan: LEONARD HELFGOTT

Anthropology and Sociology: MICHAEL E. BONINE

Language and Literature: ROGER ALLEN

Other: JERE L. BACHARACH

Film Reviews: Charlotte F. Albright

Record Reviews: HIROMI L. SAKATA

Outreach Programs: CharlotTe F. AlbRIGHT

Art and Exhibitions: IRENE A. BIERMAN

COMMUNICATIONS FOR THE EDITOR should be addressed to JERE L. BACHARACH, Department of History, University of Washington, Seattle, Washington 98195.

BOOKS AND AUDIOVISUAL MATERIALS FOR REVIEW are to be sent to The Middle East Studies Association, Headquarters and Secretariat, Department of Oriental Studies, University of Arizona, Tucson, Arizona 85721, (602) 621-5850. Books received are listed in the MESA Newsletter.

THE MESA BULLETIN (ISSN 0026-3184) is a biannual publication of the Middle East Studies Association of North America, Inc., issued in July and December. Views expressed in the Bulletin are those of the authors and do not necessarily represent those of the Association.

(C) 1984 by The Middle East Studies Association of North America, Inc.

Printed in the United States of America.

Distributed by The Cambridge University Press. 
Middle $E_{\text {ast }} S_{\text {tudies }}$ Association BULLETIN

Paul Chevedden, Making Light of Everything:

Early Photography of the Middle East and

Current Photomania

Jill CRYstal, Research Facilities in the Arabian Gulf:

Kuwait, Bahrein, Oman, Qatar, and the United Arab Emirates

BOOK REVIEWS

\section{Anthropology and Sociology}

FERHAD IBRAHIM, Die kurdische Nationalbewegung im Irak

(Thomas Philipp)

AIDa Kanafani, Aesthetics and Ritual in the United Arab Emirates (Evelyn A. Early)

B. F. Musallam, Sex and Society in Islam: Birth Control before the Nineteenth Century (Michael W. Dols)

G. P. SNESAREV, Khorezmskiie legendy kak istochnik po istorii religiozniykh kul'tov Srednei Azii (Marina Tolmacheva)

RICHARD TAPPER ed., The Conflict of Tribe and State in Iran and Afghanistan (Amir Ismail Ajami)

\section{History and Economics before 1900}

SHLOMO DESHEN, Sibur ve-yehidim be-Maroqo: sidre ha-hevra be-qehillot ha-yehudim be-me'ot ha-18-19 (Daniel Schroeter)

FRED MCGRAW DONNER, The Early Islamic Conquests (C. F. Petry)

LeIla TARAZI FAWAZ, Merchants and Migrants in Nineteenth Century Beirut (Iliya Harik)

NANCY Elizabeth Gallagher, Medicine and Power in

Tunisia, 1780-1900 (Fady Hajal) 
Joel L. Kraemer \& Ilai Alon eds, Religion and Government in the World of Islam (Richard W. Bulliet)

RUdi PAUl Lindner, Nomads and Ottomans in Medieval Anatolia (Cornell H. Fleischer)

Ehud R. Toledano, The Ottoman Slave Trade and Its Suppression: 1840-1890 (Joseph C. Miller)

ANDREW M. WATSON, Agricultural Innovation in the Early Islamic World: The Diffusion of Crops and Farming Techniques, 700-1100 (R. W. Bulliet)

203

\section{Modern History, Political Science, and Economics}

F. DAvid ANDrEws ed., The Lost Peoples of the Middle East: Documents of the Struggle for Survival of the Kurds, Assyrians, and Other Minority Races in the Middle East (John Joseph)

205

L. CARL Brown, International Politics and the Middle East: Old Rules, Dangerous Game (Benjamin Braude)

Ali E. HILAL DessoukI ed., Islamic Resurgence in the Arab World (Michael C. Hudson)

FinN Fuglestad, A History of Niger, 1850-1960 (Allan Christelow)

JOSEPH GORNY, The British Labour Movement and Zionism (Sara Reguer)

NICHOLAS S. HOPKINS, Testour ou la transformation des campagnes maghrebines (Mira Zussman)

SAAD EDdin IBRAHIM, The New Arab Social Order: A Study of the Social Impact of Oil Wealth (Michael C. Hudson)

GUDRUN KRÄMER, Minderheit, Millet, Nation? Die Juden in Ägypten 1914-1952 (Mark Epstein)

DENIS MACEVIN \& AHMED AL SHAHI eds., Islam in the Modern World (John L. Esposito)

THOMAS MAYER, Egypt and the Palestine Question, 1936-1945

(Wilfrid W. Rollman)

GUITY NASHAT ed., Women and Revolution in Iran (Azar Tabari) 218

DONALD REID, Lawyers and Politics in the Arab World, 1880-1960 (Charles Bashara)

ROBERT W. RYCROFT \& JOSEPH S. SZYLIOWICZ,

Decision-Making in a Technological Environment:

The Case of the Aswan High Dam (James Jankowski)

Muhammad NeJatullah SiDdiqI, Muslim Economic Thinking (Joseph S. Szyliowicz)

Muhammad NeJATUllaH SiddiQI, Issues in Islamic Banking (Ann Elizabeth Mayer) 
JOSEPH S. SZYLIOWICZ, Planning, Managing and

Implementing Technological Development Projects: The Case of the Eregli Iron and Steel Works (Donald Quataert)

STEPHEN E. TABACHNICK ed., The T. E. Lawrence Puzzle

(Sheila Ann Scoville)

MAHMUD TALEGHANI, Society and Economics in Islam: Writings and Declarations of Ayatullah Mahmud Taleghani (Mangol Bayat)

ROBERT L. Tignor, State, Private Enterprise, and Economic Change in Egypt, 1918-1952 (Joel Beinin)

\section{Humanities and Research Tools}

C. ADLE] ed., Art et société dans le monde iranien (Irene A. Bierman)

KHURSHID AHMAD \& ZAFAR ISHAQ ANSARI eds., Islamic Perspectives: Studies in Honour of Mawlānā Sayyid Abul A'lā Mawdūdī (Michael Fisher)

AhMAD AmIN, Orient and Occident (Selma Botman)

MAHMOUD M. AYOUB, The Qur'an and Its Interpreters 1 (Muhammad S. Eissa)

RENÉ BRAVMANN, African Islam (Eleanor Sims)

Michael Darby, The Islamic Perspective: An Aspect of British Architecture and Design in the 19th Century (Walter B. Denny)

DAVID EDE et al., comps., Guide to Islam (Janet Heineck)

JOHN L. EsPOSITO ed., Voices of Resurgent Islam (Michael A. Sells)

TARIQ JAWAD AL-JANABI, Studies in Medieval Iraqi Architecture (Irene A. Bierman)

DONALD KING \& DAVID SYLVESTER sel., The Eastern Carpet in the Western World from the Fifteenth to the Nineteenth Century, \&

JoHn THOMPSON, Carpet Magic: The Art of Carpets from the Tents, Cottages, and Workshops of Asia (Walter B. Denny)

Michael E. Marmura ed., Islamic Theology and Philosophy: Studies in Honor of George F. Hourani (A. Kevin Reinhart)

Johannes Pedersen, The Arabic Book (S. A. Bonebakker)

ANNEMARIE SCHIMMEL, Calligraphy and Islamic Culture (Lisa Golombek)

AMNON SHILOAH, The Musical Tradition of Iraqi Jews: Selection of Piyyutim and Songs (Edwin Seroussi)

PESSAH SHINAR, Essai de bibliographie sélective et annotée sur l'Islam maghrébin contemporain: Maroc, Algérie, Tunisie, Libye (1830-1978) (Julia Clancy-Smith) 
MARIANNA S. SimPSON, L'Art islamique, Asie: Iran, Afghanistan, Asie Centrale et Inde (Glenn D. Lowry)

Mohamed M. EL SIOUFI ed., A Fatimid Harah: Its Physical Social, and Economic Structure, \&

HaSAN-UdDin Khan ed., Mimar: Architecture in Development 10 (Walter B. Denny)

JOSEPh R. STRAYER ed., Dictionary of the Middle Ages 1-4 (Caroline Walker Bynum)

AsParukh Velkov \& STEFan ANDREeV, Vodni znatsi $v$ osmanoturskite documenti 1.Tri Luni (Daniel Clarke Waugh)

John Vollmer, E. J. KeAll, \& E. NAGAI-Berthrong, Silk Roads, China Ships (Miriam Rosen)

\section{Short Notices}

KAISER \& STEINBACH eds., Deutsch-arabische Beziehungen

LAPIDUS, Muslim Cities in the Later Middle Ages

STRAYER ed., Dictionary of the Middle Ages 2

REVIEWS OF AUDIOVISUAL MATERIALS

Islam, a Pictorial Essay in Four Parts \&

World of Islam, videotapes (Ellen-Fairbanks Bodman)

Peter S. Allen \& Carole Lazio eds., Archaeology on Film: A Comprehensive Guide to Audio-Visual Materials (Ellen-Fairbanks Bodman)

NANCY R. SAVIN, prod., Legacy of the Mamluks, videotape 267

NEWS OF THE ASSOCIATION 268

RECENT CONFERENCES $\quad 272$

NEWS OF FELLOWS AND SCHOLARS

EDITORIAL 297

COVER: Damascus. East Gate (Bāb Sharq̄i). Frith 1858.

Francis Frith, Egypt and Palestine Photographed and Described, 2 vols. in 1 (London: J. S. Virtue, $[1858-60]$ ), pl. 20 of copy 3 in the Department of Special Collections, University Research Library, University of California, Los Angeles. See Making Light of Everything, by Paul E. Chevedden, page 162. All the photographs in this article were provided courtesy of the Department of Special Collections, University Research Library, UCLA. 